\title{
Research on College English Teachers' Information Literacy in Information Environment
}

\author{
Du Yan-xia ${ }^{1}$ \\ ${ }^{1}$ English Department, North China Electric Power University, Baoding, Hebei, China \\ Correspondence: Du Yan-xia, English Department, North China Electric Power University, Baoding, Hebei, \\ China. E-mail: dyxanna@163.com
}

$\begin{array}{lc}\text { Received: August 14, } 2017 & \text { Accepted: October 5, } 2017 \quad \text { Online Published: October 8, } 2017 \\ \text { doi: } 10.5539 / \text { elt.v11n10p37 } & \text { URL: http://doi.org/10.5539/elt.v11n10p37 }\end{array}$

\begin{abstract}
The new technology revolution based on Internet, information and communication technology has triggered an upsurge of educational information in the world, including English learning and teaching. The improvement of teacher's information literacy is the key to the success of the current educational informatization reform. From the perspectives of the concept of information literacy and the particularity of English teachers' professional development, this paper makes a series of questionnaires. Survey results show that there are some problems in the present situation of English teachers' information literacy. Therefore, this paper puts forward the following strategies to improve teachers' information literacy: improving self-development consciousness, perfecting modern information technology training system, improving the integration ability of information technology and English classroom, and accelerating the development of English teaching resources platform.
\end{abstract}

Keywords: information literacy, information consciousness, information ability, college English teachers

\section{Introduction}

Today, with the deep development of educational informatization, information technology has become an indispensable part for modern education. Providing more resources than ever before for English teaching, information technology is the guarantee for the smooth progress of English teaching. Hence, it is necessary to promoting the reform of college English teaching and construct information teaching mode. However, in order to realize the normalization of network information technology in English classroom, compared to hardware and software development, "humanware" construction plays a crucial role (Chen, 2010). Because the degree of teachers' participation is actually the decisive factor in the popularization and application of any educational technology, as the dominant conductors, College English teachers are of vital importance for the development of computer multimedia teaching. Nevertheless, the mode, which focuses only on language teaching, can no longer meet the needs of teachers' development in the context of educational reform. College English teachers must adapt themselves to the situation of information teaching, renew their teaching ideas, improve their information literacy so as to guarantee the smooth progress of College English teaching reform and realize the sustainable development of their profession.

The term "Information Literacy" was advanced initially by Paul G. Zurkowski. He described it as "techniques and skills" acquired by the information literate "for utilizing the wide range of information tools as well as primary sources in molding information solutions to their problems". While many scholars and associations put forward different definitions according to the need in different terms, "the ability to solve information questions" is the consistent core of the definition. At present, the definition recognized universally was proposed by American Library Association, which is "a set of abilities requiting individuals to 'recognize' when information is needed and have the ability to locate, evaluate, and use effectively the needed information". Based on the definitions at home and abroad, Chinese scholar, Chen Jian-lin (2010) pointed out that information literacy refers to a comprehensive ability that enable a person to recognize when information is needed, and to search, evaluate and use information effectively, and then to process, sort, refine and innovate the acquired information, so as to obtain new knowledge. Chinese scholars generally believe that information literacy is a comprehensive ability consisting of information consciousness and information ability. Information consciousness is the total of knowledge, idea and demand produced by people in information activities, while information ability mainly refers to the ability to understand and acquire information, process and handle information, integrate and use 
information by means of information technology. Hence, under the trend of complicated teaching environment and diversified teaching mode, the army of English teachers and relevant scholars need to explore how to improve information consciousness and develop information ability.

\section{The necessity of teachers' information literacy development}

\subsection{College English Teachers' Information Literacy is the Key to College English Teaching Reform}

With the advancing of education, there has been a tremendous teaching revolution in the world. In China, the "Ten years of education informationization development plan (2011-2020)" formulated by the Ministry of education in 2012 clarifies the guiding ideology and strategic objectives of the educational informatization in China, and points out the revolutionary impact of information technology on education and the leading role in the reform of education. Therefore, in order to adapt to the requirements of social development and scientific progress, higher education should strengthen the integration with technology and speed up the process of educational modernization through educational informationization. Education informatization has promoted the reform of foreign language teaching which takes information technology as its core. College English course should keep pace with the times, and combine information technology with classroom teaching effectively so as to give full play to the important role of modern educational technology. This change poses great challenges to college English teachers, but it also provides an environment and a platform for their professional development.

Nowadays, to teachers, modern educational information technology is the basic and core course rather than an additional requirement. Therefore, College English teachers must have good information literacy to adapt to the development trend of education informatization. "College English Curriculum Requirements" promulgated by the Ministry of education in 2007 pointed out: "The quality of teachers is not only the key to improve the quality of teaching, but also the key to the construction and development of College English". Consequently, under such information requirements, college English teachers should actively change traditional teaching idea, improve teaching ability, enhance their information literacy, make full use of modern information technology, and eventually change the mode of English teaching. Teachers' information literacy is crucial to the realization of new teaching mode. Chen Jian-lin (2004) pointed out: Teachers' information literacy determines whether college teaching reform will succeed or not, and it is also critical to the development of discipline in long term. Similarly, many researches (Kramsch \& Andersen, 1999; Warschauer \& Meskill, 2000; Strambi \& Bouvet, 2003) sates that the teachers who possess positive information literacy can adapt themselves to the requirements of the teaching reform and integrate the information technology with the English class so as to improve the teaching effect.

\subsection{Information Literacy is Crucial to the Professional Development of College English Teachers}

Multimedia and network assisted teaching mode is the current prevalent teaching mode in China, which is also recommended by teaching revolution. Based on this mode, teachers should integrate various media, technologies and resources into English teaching, and moreover teachers are also supposed to collect, process, store and apply these resources, so as to optimize the environment of College English teaching. Therefore, this English teaching environment has brought new demands and challenges to the quality of College English teachers. It requires teachers to have certain information literacy besides essential language competence. Thus, teachers' information literacy has become the most component of a teacher's knowledge structure, which determines teachers' future professional development. On the other hand, good information literacy of College English teachers can help teachers adhere to lifelong learning and constantly update their knowledge so as to promote their professional development. What's more, information technology plays a great role in teacher education, and information technology itself is beneficial for professional development of teachers( Davis, 1999; Pearson, 2003 ). Hence, good information literacy is helpful for teachers to promote their professional development by means of information technology.

On the whole, College English teachers should not only make good use of information technology to assist college English teaching, but also use information technology to develop themselves actively. The information literacy of College English teachers has become an important guarantee for their professional development. Meanwhile, many researchers (Etta \& Elder, 2005; HE An-ping, 2008; Qin \& He, 2009 etc.) pointed out: English teachers who possess good information literacy can effectively integrate information technology into English teaching, create a more authentic language learning environment, promote meaningful language input and output, improve the efficiency of student learning, enhance students' autonomous learning ability. From this perspective, teachers should excel in applying information technology to assist college English teaching. In the process of learning and mastering information technology, teachers are also supposed to develop themselves actively by information technology. Accordingly, regardless of teaching revolution or teachers' own professional development, college English teachers who are in this information ear must be armed with great information 
literacy.

\section{The Present Situation of College English Teachers' Information Literacy}

\subsection{The Investigation of College English Teacher's Information Literacy}

In order to know the present situation of college English teachers' information literacy and find methods and strategies for improving teachers' information literacy, this study designs questions from the perspectives of information consciousness and information ability. The subjects of this investigation are college English teacher from three universities in Hebei Province of China. Adopting random sampling method, a total of 100 questionnaires were sent out and 98 were recovered, among which 95 were valid questionnaires.

\subsection{Statistic and Analysis of the Results}

\subsubsection{Most of the Teachers Have Strong Information Consciousness}

It is can be seen from the statistics (see Table 1) that most of the teachers have information consciousness, but there are still a considerable number of teachers who think that the requirement of educational informatization is too high. While the teachers recognize the importance of educational information technology to the teaching level, they question the effectiveness of information technology subconsciously. On the other hand, most teachers are keen on further studying to improver their information technology competence, which indicates that teachers are still motivated. The reasons why they are unable to put this desire into practice are as follows: heavy working burden, time and energy deficiency, no relevant training, the age, etc.

Generally speaking, the current teachers have a wealth of basic theoretical knowledge of modern education. They are familiar with the concepts and principles of teaching design, understand the steps and rules of teaching methods, and are receptive to new theories of education and teaching. With the deepening of English teaching reform, college English teachers are more fully aware of the importance and necessity of modern educational technology, and have a strong sense of learning. However, their familiarity with the basic theory of modern educational technology is not high, and they lack the experience of applying theory to practice. By and large, English teachers generally have a positive attitude towards information technology, but the deficiency of relevant information technology impedes the application to practical teaching. On balance they can correctly recognize the potential and advantages of information technology to traditional teaching. However, under the overlapping of the old and new teaching ideas, they are at a loss as to how to adjust original teaching principles, design, methods, and structure.

Table 1. The investigation of college English teacher's information literacy

\begin{tabular}{|c|c|c|c|c|c|c|}
\hline \multirow{2}{*}{$\begin{array}{l}\text { Do you know information } \\
\text { technology? }\end{array}$} & Vey well & Well & \multicolumn{2}{|l|}{ A little } & No interest & No \\
\hline & $6 \%$ & $20 \%$ & \multicolumn{2}{|l|}{$45 \%$} & $12 \%$ & $15 \%$ \\
\hline \multirow{2}{*}{$\begin{array}{l}\text { Do you think modern } \\
\text { information technology can } \\
\text { improve efficient of English } \\
\text { teaching? }\end{array}$} & absolutely & Sure & \multicolumn{2}{|c|}{ Unclear } & Maybe yes & No \\
\hline & $18 \%$ & $48 \%$ & $12 \%$ & & $14 \%$ & $7 \%$ \\
\hline \multirow{2}{*}{$\begin{array}{l}\text { Have you ever applied } \\
\text { information technology to } \\
\text { English teaching? }\end{array}$} & Frequently & \multicolumn{2}{|c|}{ Once in a while } & \multicolumn{2}{|c|}{ When necessary } & Never \\
\hline & $30 \%$ & $50 \%$ & & $15 \%$ & & $5 \%$ \\
\hline \multirow{2}{*}{$\begin{array}{l}\text { Do you think it necessary for } \\
\text { teachers to develop their skills in } \\
\text { information technology? }\end{array}$} & $\begin{array}{l}\text { Highly } \\
\text { necessary }\end{array}$ & Yes & \multicolumn{2}{|c|}{ Unclear } & A little & No \\
\hline & $24 \%$ & $58 \%$ & $9 \%$ & & $6 \%$ & $3 \%$ \\
\hline \multirow{2}{*}{$\begin{array}{l}\text { Would you like to make great } \\
\text { efforts to study and use various } \\
\text { information tools for improving } \\
\text { the quality of English teaching? }\end{array}$} & Very willing & \multirow{2}{*}{\multicolumn{2}{|c|}{$\begin{array}{l}\text { Just so so } \\
30 \%\end{array}$}} & \multicolumn{3}{|c|}{ No } \\
\hline & $62 \%$ & & & & $8 \%$ & \\
\hline
\end{tabular}

\subsubsection{Their Information Ability Is Not Good, and the Actual Operation Ability Needs to be Strengthened}

The results of the survey (see Table 2) reveal that a majority of English teachers understand basic computer knowledge and be able to adapt to the change of teaching environment, but their practical technical ability is 
poor. Firstly, teachers are familiar with common information technology tools and applied to English teaching, for instance, almost all of the teachers are able to design and make multimedia courseware. Nevertheless, as to the difficulty of video and audio processing, they are less incompetent. Secondly, most of the teachers have the information retrieval and selection ability, and can use the Internet for daily work, such as office system, online scoring, online course evaluation, but network teaching platform development, and website design and construction technology are still relatively weak. In addition, most teachers can carry out academic research through the Internet and communication tools, but they lack ability of information development, sharing, communication and innovative use. All of the data indicate that college English teachers' ability of technique application is in the initial stage and needs further promotion.

Table 2. Investigation on college English teachers' mastery of information technology

\begin{tabular}{llllll}
\hline Investigation content & \multicolumn{3}{l}{ Results } & & \\
\cline { 2 - 6 } & Good & Mediocre & Unclear & Not good & poor \\
\cline { 2 - 6 } Basic computer knowledge & $32 \%$ & $31 \%$ & $27 \%$ & $7 \%$ & $3 \%$ \\
Internet information exchange & $5 \%$ & $21 \%$ & $28 \%$ & $24 \%$ & $20 \%$ \\
Information retrieval and selection & $16 \%$ & $36 \%$ & $20 \%$ & $18 \%$ & $10 \%$ \\
Design and making of courseware & $20 \%$ & $45 \%$ & $12 \%$ & $16 \%$ & $7 \%$ \\
Construction and design of website & $2 \%$ & $10 \%$ & $20 \%$ & $45 \%$ & $23 \%$ \\
Image and video processing & $7 \%$ & $18 \%$ & $28 \%$ & $32 \%$ & $13 \%$ \\
Audio processing & $10 \%$ & $24 \%$ & $23 \%$ & $29 \%$ & $14 \%$ \\
Design of network course & $9 \%$ & $20 \%$ & $38 \%$ & $27 \%$ & $6 \%$ \\
Design and development of teaching platform & $14 \%$ & $22 \%$ & $23 \%$ & $29 \%$ & $12 \%$ \\
Design and analysis of teaching environment & $13 \%$ & $17 \%$ & $22 \%$ & $34 \%$ & $14 \%$ \\
\hline
\end{tabular}

Given above, college English teachers posses some knowledge of information literacy, but most remain in the basic level, lacking middle-and high-end informationalized teaching skill. Up to $64 \%$ of teachers have the positive attitude towards the integration of multimedia network technology and English teaching to improve teaching quality and learning efficiency, but less than $50 \%$ of the teachers are proficient in the application of information technology to create various kinds of teaching environment. Furthermore, $40 \%$ of the teachers can not integrate the acquired information into the classroom and their own research activities. All of the date indicate that English teachers' competence to integrate information technology into teaching is less impressive, which results in the low rate of the transformation of information technology into English teaching, and there is a big gap between it and the requirement of modern English teaching.

\section{The Promotion Strategy of College English Teachers' Information Literacy}

\subsection{Improve Self-Development Consciousness}

The rapid development of information technology and Internet has not only triggered a revolutionary in educational informatization, but also contributed to the transformation of traditional teachers' education concepts. "College English Curriculum Requirements"(2007) highlights that "The change of College English teaching mode is not just the change of teaching methods and means, but also the change of teaching idea. It is the conversion from the teaching patterns in which teachers simply instruct the linguistic knowledge and skills into the teaching patterns in which teachers can instruct the general linguistic knowledge and skills, meanwhile train the ability of practicing language and the ability of students 'self-study. It is the change that more attention should be paid to the teaching thought and practice of developing the ability of practical application of language and autonomous learning. It is also the change to realize lifelong education oriented to train students' lifelong learning ability" Therefore, in this information age, teachers have translated from initiator and supervisor of knowledge into promoters, participators and guides of students. Thus, college English teachers are supposed to realize the particularity of the professional development of teachers under information environment and the commonplace between language teachers and the teachers of educational subjects, establish correct belief of teachers, change the traditional teaching idea, and strengthen information consciousness. 
The consciousness of information, as a prerequisite for English teachers to acquire knowledge, determines the degree of the teacher's awareness of catching and using information, which is also the base and premise of teachers' professional development. The new knowledge and new skills created in the information environment are urgently needed and supplemented in the knowledge structure of the teachers themselves by the teachers. This kind of academic structural adjustment requires teacher to establish the consciousness of relearning. MAO Ming-yong (2007) hold that teachers should be fully aware of the five advantages of information and communication technology, including a positive role in creating a pleasant English communication environment, a positive role in developing students' thinking abilities, a positive role in greatly improve the teaching efficiency, a positive role for students to construct cognitive schemata, and a positive role for teachers to do more teaching reflection. Accordingly, under the network environment, English teachers should fully recognize the superiority of information technology, employ the cyber source rationally, change the roles of teachers actively, update teaching ideas, eventually adapt to the information age education. On the whole, English teachers should take the information technology as the support, to promote the development of college English teaching and students' personalized autonomous learning. Nonetheless, some issues inevitably arise during the course of foreign language teaching reform, such as teachers' unstable belief, misconception about informatization teaching. To solve these issues, on the one hand, teachers should have the sense of urgency to renew the concept, learn new technologies and concepts actively, adjust and construct the knowledge system, so as to strengthen the sense of independent development. On the other hand, school authorities should support teachers in the aspects of material, policy and time. They are expected to pay attention to the existence and development of college English teachers, give teachers more humanistic care, and actively create an ecological and harmonious social and cultural environment to provide a good platform for teachers' professional development

\subsection{Perfect Modern Information Technology Training System}

It is surveyed that the needs of English teachers' information technology training are divided into two aspects: teaching and scientific research. $82 \%$ of teachers think it is urgent to design and develop multimedia courseware and network courseware. $62 \%$ of the teachers would like to be trained in the use of application software such as Flash production, audio and video production, and later editing. Up to $93 \%$ of teachers want to get the training of mainstream social statistics software, especially SPSS software, to enhance research capacity and level, on the contrast, in reality, only 3\% of English teachers have the ability to use SPSS software. Teachers who have been engaged in teaching for a long time are keen to capture the combination of information technology and research. Therefore, it is necessary to fully understand the needs of teachers in the process of carrying out information literacy training, determine specific training content, and enhance the pertinence of training. According to the research results, it is suggested that universities should arrange training of multimedia courseware design and development and application software, such as SPSS, Total recorder, Video splitter, Photoshop, Macromedia flash. This targeted training can not only improve the English teachers' teaching ability of information technology, but greatly promote their innovation of teaching and research, ultimately achieve the following ideal effect: teachers are able to learn to think, learn to apply, and learn to achieve.

\subsection{Improve the Integration Ability of Information Technology and English Classroom}

The integration of information technology and foreign language curriculum is essentially a new and efficient way of teaching foreign languages. It is an organic combination of information technology, information resources, information methods and curriculum content in the process of foreign language teaching. This integration has two levels of meaning: on the one hand, teachers use information technology resources to teach; on the other hand, students use information technology and resources to explore and learn. From the current situation, English teachers have basic information literacy and pay attention to the application of new technologies. However, there are some confusion in the understanding and implementation of the integration of English courses and information technology. Some teachers confuse the idea of "assistance" and "integration". They think that computer assisted instruction or learning is integration, or the use of multimedia courseware is equivalent to integration. There are still some teachers who overuse information technology, which leads to more technology than language learning in classroom.

Hence, to realize integration, teachers must clearly understand the characteristics of English disciplines and teaching materials, make innovations in teaching ideas and methods, and effectively evaluate teaching process and learning activities in the multimedia network environment. In the first place, teachers should handle the status of technology in the course. The purpose of using technology is to serve the teaching. As the users and operators of information technology, the creative use of technology of teachers can make the technology serve the curriculum, and eventually truly realize the key influence of information technology. In the second place, 
teachers should effectively integrate their own information literacy into the teaching practice. Teachers may employ digital technology to reorganize and create the content of English teaching, and try developing their own online course. Additionally, teachers may use the network and other information technology to select the relevant teaching content for classroom display, so that language and practice can merge together. Generally, technology, as a teaching tool and learning tool, runs through the whole process of learning and creates a virtual reality environment. Through these foreign language teaching practices, teachers can cultivate information awareness in the digital teaching environment and process, and constantly improve their own information literacy.

\subsection{Accelerate the Development of English Teaching Resources Platform to Effectively Realize the Sharing of Resources}

The development of information technology in education is bound to change the situation in which teachers work alone, so as to promote the transformation of teachers from individual learning to team cooperation. College English teachers need a large amount of information resources in the process of teaching and research, while the resources that are searched on the network have little to be used directly, so it takes teachers lots of time and energy to arrange and process the resources. Under such situation, it is necessary to accelerate the development of school-based English teaching resources platform. On this platform, educational resources can be grouped into different categories, such as courseware, listening, writing, discussion and answering. Teachers and students are encouraged to set up personal teaching and learning space on the platform and upload resources to realize the sharing of high-quality teaching resources. This will not only ensure the continuity and growth of information interaction, but also give full play to the initiative of teachers in information acquisition and sharing.

Meanwhile, teachers can use platform to carry out scientific research activities. Cooperation is very important in scientific research activities for English teachers. Without cooperation, great breakthroughs can not be achieved. Teachers can use the network platform to evaluate and consider each other's teaching and research achievements, so as to foster network evaluation ability. Based on the virtual environment, this platform creates a relatively free, equal, personalized and efficient online learning environment for teachers. In short, the construction of the network platform can satisfy the needs of English teachers in exchanging and sharing the multitude information to obtain the best benefit of scientific research.

\section{Conclusion}

Network information technology has penetrated into every aspect of education and teaching. The integration of information technology and English curriculum is the trend of English teaching, which not only creates ideal environment for teaching and learning, but endows foreign language teachers with new connotations of professional development in the context of information technology and proposes higher requirements for knowledge competence of foreign language teachers. Consequently, the majority of English teachers should change their ideas, and strive to improve their own information literacy to cater for the changes of teaching environment. Only when teachers grasp the opportunities given by the information age do they realize individual professional development. Without doubt, the meaning of information literacy will change and develop with the development of information society. Hence, college English teachers should focus on their own information literacy, strengthen the integration of information technology and language teaching, effectively utilize various information resources, and emphasize the exploration and research of new teaching mode. Anyhow, College English teachers' development of information literacy is the need of modern foreign language teaching and teachers' professional development. It is a long-term systematic project, which needs the relevant departments of education, school leaders and teachers work together.

\section{Acknowledgement}

This research was financially supported by the Fundamental Research Funds for the Central Universities (2014MS177).

\section{References}

Chen, J. L. (2010). The Integration of Computer Network and Foreign Language Classroom. Shanghai : Shanghai foreign language education publisher.

Chen, J. L. (2004). Theoretical Connotation and Application Analysis of College English Network Teaching. Computer-assisted Foreign Language Education, (6), 46-50.

Davis, N. (1999). Teacher Education and Information Technology: Challenges for Teacher Education. Journal of Information Technology for Teacher Education, (1), 3-13. 
Etta, F., \& Elder, L. (2005). At the Crossroads: ICT Policymaking in East Africa. Africa: East African Educational Publishers.

HE An-ping. (2008). How does Corpus Come into Classroom Teaching. Foreign Language Education in China, (4), 8-12.

Kramsch, C., \& Andersen, R. W. (1999). Teaching Text and Context through Multimedia. Language Learning \& Technology, (2), 31-42.

Pearson, J. (2003). Information and Communications Technologies and Teacher Education in Australia. Technology, Pedagogy and Education, (1), 39-58.

Mao, M. Y. (2007). Analysis of Ability of College English Network Teaching teachers. Foreign Language World, (2), 26-31

Qin, M. J., \& He, G. K. (2009). Discussion on the Connotation of College English Teachers' Information Literacy. Foreign Language World, (5), 18-25.

Strambi, A., \& Bouvet, E. (2003). Flexibility and Interaction at a Distance: A mixed-mode Environment for Language Learning. Language Learning \& Technology, (7), 81-102.

Warschauer, M., \& Meskill, C. (2000). Technology and Second Language Teaching and Learning. In J. Rosenthal (Ed.). Handbook of Undergraduate Second Language Education. Mahwah, NJ: Lawrence Erlbaum.

Wu, X. (2017). On EFL Teachers'Information Literacy and Professional Development in Information Environment. Journal of Yulin University, (5), 113-116.

Yu, S. Q. (2010). The Integration of Information Technology and Curriculum. Shanghai: Shanghai foreign language education publisher.

Zurkowski, P. G. (1974). The Information Service Environment Relationships and Priorities. Washington, D.C.: National Commission on Libraries and Information Sciences.

\section{Copyrights}

Copyright for this article is retained by the author(s), with first publication rights granted to the journal.

This is an open-access article distributed under the terms and conditions of the Creative Commons Attribution license (http://creativecommons.org/licenses/by/4.0/). 